\title{
Tissue distribution of oral vitamin B12 is influenced by B12 status and B12 form: an experimental study in rats
}

\author{
Linda S. Kornerup ${ }^{1} \cdot$ Sergey N. Fedosov $^{2} \cdot$ Christian B. Juul $^{2} \cdot$ Eva Greibe $^{1} \cdot$ \\ Christian W. Heegaard ${ }^{2} \cdot$ Ebba Nexo $^{1}$
}

Received: 27 September 2016 / Accepted: 27 February 2017 / Published online: 20 March 2017

(c) The Author(s) 2017. This article is an open access publication

\begin{abstract}
Purpose Hydroxocobalamin ( $\mathrm{HOCbl}$ ) is the dominating $\mathrm{Cbl}$ form in food, whereas cyanocobalamin $(\mathrm{CNCbl})$ is common in vitamin pills and oral supplements. This study compares single-dose absorption and distribution of oral $\mathrm{HO}\left[{ }^{57} \mathrm{Co}\right] \mathrm{Cbl}$ and $\mathrm{CN}\left[{ }^{57} \mathrm{Co}\right] \mathrm{Cbl}$ in Cbl-deficient and normal rats.

Methods Male Wistar rats (7 weeks) were fed a 14-day diet with $(n=15)$ or without $(n=15) \mathrm{Cbl}$. We compared the uptakes of $\mathrm{HO}\left[{ }^{57} \mathrm{Co}\right] \mathrm{Cbl}$ (free or bound to bovine transcobalamin) and free $\mathrm{CN}\left[{ }^{57} \mathrm{Co}\right] \mathrm{Cbl}$ administered by gastric gavage ( $n=5$ in each diet group). Rats were sacrificed after $24 \mathrm{~h}$. Blood, liver, kidney, brain, heart, spleen, intestines, skeletal muscle, 24-h urine and faeces were collected, and the content of $\left[{ }^{57} \mathrm{Co}\right] \mathrm{Cbl}$ was measured. Endogenous $\mathrm{Cbl}$ in tissues and plasma was analysed by routine methods.

Results Mean endogenous plasma-Cbl was sevenfold lower in deficient vs. normal rats (190 vs. $1330 \mathrm{pmol} / \mathrm{L}$, $p<0.0001)$. Cbl depletion increased endogenous $\mathrm{Cbl}$ ratios (tissue/plasma $=k_{\text {in }} / k_{\text {out }}$ ) in all organs except for the kidney, where the ratio decreased considerably. Twenty-four-hour accumulation of labelled $\mathrm{Cbl}$ showed that $\mathrm{HOCbl}>\mathrm{CNCbl}$ (liver) and $\mathrm{CNCbl}>\mathrm{HOCbl}$ (brain, muscle and plasma).
\end{abstract}

Electronic supplementary material The online version of this article (doi:10.1007/s00394-017-1424-0) contains supplementary material, which is available to authorized users.

Linda S. Kornerup

lindajen@rm.dk

1 Department of Clinical Biochemistry, Aarhus University Hospital, Palle Juul-Jensens Boulevard 998200 Aarhus N, Denmark

2 Department of Molecular Biology and Genetics, Aarhus University, Aarhus, Denmark
Conclusions The $\mathrm{Cbl}$ status of rats and the administered $\mathrm{Cbl}$ form influence 24-h $\mathrm{Cbl}$ accumulation in tissues and plasma.

Keywords Hydroxocobalamin - Cyanocobalamin . Intestinal absorption $\cdot$ Cobalamin deficiency $\cdot$ Kinetic modelling
Abbreviations
AdoCbl 5'-Deoxyadenosyl-Cbl
ALAT Alanine aminotransferase
Cbl Cobalamin/vitamin B12
$\mathrm{CNCbl}$ Cyano-Cbl
HOCbl Hydroxo-Cbl
$\mathrm{MeCbl}$ Methyl-Cbl
MMA Methylmalonic acid
TC Transcobalamin
T4 Thyroxin
T3 Triiodothyronine

\section{Introduction}

Vitamin B12 (cobalamin, Cbl) is essential for a normal neurological function and formation of blood cells. The vitamin is supplied via dietary animal products and increasingly through food fortification or vitamin pills [1]. The $\mathrm{Cbl}$ forms present in foods are the coenzymes methyl- and 5'-deoxyadenosyl-Cbl (MeCbl, AdoCbl). A brief exposure to light converts both coenzymes to hydroxo-Cbl (HOCbl), making HOCbl the ubiquitous food form of $\mathrm{Cbl}$ [2]. Cyano$\mathrm{Cbl}(\mathrm{CNCbl})$ is chemically stable, and it is the predominant $\mathrm{Cbl}$ form used in industrial Cbl products (food fortification and vitamin pills) [3]. The general concept is that HOCbl and $\mathrm{CNCbl}$ are comparable concerning their absorption and 
tissue distribution patterns, while free $\mathrm{Cbl}$ is absorbed more efficiently than food bound $\mathrm{Cbl}$ (for a review see ref. [3]). Our recent data in normal rats challenge both of these statements [4]. We compared 24-h oral absorption of $\mathrm{CN}\left[{ }^{57} \mathrm{Co}\right]$ $\mathrm{Cbl}$ (free or bound to bovine transcobalamin (TC), the $\mathrm{Cbl}$ binding protein in milk) and free $\mathrm{HO}\left[{ }^{57} \mathrm{Co}\right] \mathrm{Cbl}$. We found no difference between TC-bound and free $\mathrm{CN}\left[{ }^{57} \mathrm{Co}\right] \mathrm{Cbl}$, as well as no difference in the total absorption levels of the two $\mathrm{Cbl}$ forms. However, the liver $\mathrm{HO}\left[{ }^{57} \mathrm{Co}\right] \mathrm{Cbl}$ accumulation was twice as high as the $\mathrm{CN}\left[{ }^{57} \mathrm{Co}\right] \mathrm{Cbl}$ accumulation. Notably, this result challenges the concept that $\mathrm{CN}\left[{ }^{57} \mathrm{Co}\right]$ $\mathrm{Cbl}$ and $\mathrm{HO}\left[{ }^{57} \mathrm{Co}\right] \mathrm{Cbl}$ behave alike and thereby are of equal value for treatment/prevention of Cbl deficiency.

The current study was undertaken to investigate whether the observed differences in distribution of HOCbl and $\mathrm{CNCbl}$ also were mirrored in other tissues than liver and kidney and whether this distribution was dependent on $\mathrm{Cbl}$ status. In addition, we wanted to explore whether the food form of $\mathrm{Cbl}(\mathrm{HOCbl})$ was absorbed alike when administered free or bound to bovine TC.

\section{Materials and methods}

\section{Animals}

Thirty male Wistar rats (Taconic Bioscience Inc., Denmark) were used for the experiments; 7 weeks old, weighing approx. $200 \mathrm{~g}$ upon arrival to the animal facilities. The rats were housed in pairs in standard cages (Makrolon $1291 \mathrm{H}$ type III H, $800 \mathrm{~cm}^{2}$, Tecniplast, Italy) with free access to food and tap water. The room temperature was $19-20^{\circ} \mathrm{C}$ and the humidity $60 \%$ with a $12 / 12 \mathrm{~h}$ light/ dark cycle. Bedding material (asp chips, Tapvei, Finland) and soft paper wool (LBS biotech, United Kingdom) were changed daily. Rats were kept for 2 weeks, during which half $(n=15)$ were randomized to a Cbl-deficient diet (Altromin C1024, Brogaarden, Denmark) and the other half $(n=15)$ to the control diet (Altromin C1000, Brogaarden, Denmark). The calorie contents of the two diets were equal, but the Cbl-deficient diet contained less cellulose and corn starch and more sucrose compared with the control diet. The manufacturer assessed $\mathrm{Cbl}$ content by using the tabulated values for $\mathrm{Cbl}$ in different food sources. Therefore, we quantified $\mathrm{Cbl}$ in the diets by extracting $0.3 \mathrm{~g}$ of solids with $1.5 \mathrm{~mL}$ of water. After centrifugation, $\mathrm{Cbl}$ was measured in the supernatant employing a Cobas 6000 (Roche Diagnostics). During the analysis, all $\mathrm{Cbl}$ is converted to $\mathrm{CNCbl}$; thus, the Cbl content was calculated employing the molecular weight for $\mathrm{CNCbl}, \mathrm{MW}: 1355$. The mean of two independent measures is shown (Cbl-deficient diet: $<0.5(<0.5$, $<0.5) \mu \mathrm{g} / \mathrm{kg}$, control diet: $60(69,51) \mu \mathrm{g} / \mathrm{kg})$.
All experiments were conducted in agreement with EU Directive 2010/63/EU on animal experiments.

\section{Study design and experimental procedures}

The study design is depicted in Fig. 1. Each of the three subgroups received approx. $150,000 \mathrm{cpm}(0.21 \mathrm{pmol})$ of free $\mathrm{CN}\left[{ }^{57} \mathrm{Co}\right] \mathrm{Cbl}$, free $\mathrm{HO}\left[{ }^{57} \mathrm{Co}\right] \mathrm{Cbl}$ or $\mathrm{HO}\left[{ }^{57} \mathrm{Co}\right] \mathrm{Cbl}$ in complex with recombinant bovine TC (all dissolved in a $0.15 \mathrm{~mol} / \mathrm{L}$ solution of sodium chloride). The exact amount of administered radioactivity (in cpm) was calculated based on measurement of the administered volume and the cpm present in $1 \mathrm{~mL}$ of the administered solution.

Twenty-four hours prior to sacrifice, $1 \mathrm{~mL}$ of the $\mathrm{Cbl}$ solution was administered by gastric gavage. Following the oral $\mathrm{Cbl}$ dose, the rats were transferred to separate metabolic cages for $24 \mathrm{~h}$. The rats were anesthetized with isoflurane gas, and blood samples were collected by cardiac puncture into lithium-heparin tubes. Afterwards the rats were sacrificed by cervical dislocation. The liver, kidneys, spleen, heart, small intestine, muscle (thigh), brain as well as 24-h urine and faeces were collected, weighed and stored at $-80^{\circ} \mathrm{C}$ until further processing. Blood samples were centrifuged ( $9 \mathrm{~min}, 1850 \mathrm{~g}$ ), and plasma was separated and stored at $-20^{\circ} \mathrm{C}$ until analysis. Blood collection failed in 9 rats (two depleted rats receiving $\mathrm{HO}\left[{ }^{57} \mathrm{Co}\right]$ $\mathrm{Cbl}$, one depleted rat receiving $\mathrm{CN}\left[{ }^{57} \mathrm{Co}\right] \mathrm{Cbl}$, five normal rats receiving $\mathrm{HO}\left[{ }^{57} \mathrm{Co}\right] \mathrm{Cbl}$ and one normal rat receiving $\left.\mathrm{CN}\left[{ }^{57} \mathrm{Co}\right] \mathrm{Cbl}\right)$.

\section{Reagents and biochemical methods}

Commercially available preparations of $\mathrm{CN}\left[{ }^{57} \mathrm{Co}\right] \mathrm{Cbl}$ $(1.75 \mu \mathrm{Ci} / \mathrm{mL}$ and $0.41 \mu \mathrm{Ci} / \mathrm{pmol} \mathrm{Cbl})$ were used (MP Biomedicals, Ohio, USA, Catalogue no. 06B-430000). Radioactive $\mathrm{CN}\left[{ }^{57} \mathrm{Co}\right] \mathrm{Cbl}$ was converted into $\mathrm{HO}\left[{ }^{57} \mathrm{Co}\right] \mathrm{Cbl}$ by photoaquation in an acidic medium under nitrogen bubbling as previously described [4]. The purity of the conversion product was analysed by HPLC employing an in-house method [5] and found to be $>95 \%$ both at the time of production (data not shown) and after storage under conditions, known to ensure stability of the product ( $\mathrm{pH} 6.0$ at $4^{\circ} \mathrm{C}$ ) [6] for 5 months (Fig. 2).

TC was expressed as previously described [7, 8]. $\mathrm{HO}\left[{ }^{57} \mathrm{Co}\right] \mathrm{Cbl}$ complexed with TC was prepared by incubating a $10 \%$ molar excess of TC with $\mathrm{HO}\left[{ }^{57} \mathrm{Co}\right] \mathrm{Cbl}$ for $1 \mathrm{~h}$.

$\left[{ }^{57} \mathrm{Co}\right] \mathrm{Cbl}(\mathrm{cpm})$ was measured by gamma counter $(2470$ Wizard $^{2}$ Automatic Gamma Counter, Perkin Elmer, USA).

For quantification of tissue $\left[{ }^{57} \mathrm{Co}\right] \mathrm{Cbl}$ accumulation, all tissues were thawed on ice, were cut into smaller pieces if necessary and were transferred to tubes for the gamma counter. All tubes were counted to obtain the whole-organ $\mathrm{cpm}$. Intestines and contents were cut and counted together. 
Fig. 1 Study design. $\mathrm{Cbl}$ Cobalamin, $\mathrm{CNCbl} \mathrm{CN}\left[{ }^{57} \mathrm{Co}\right]$ $\mathrm{Cbl}, \mathrm{HOCbl} \mathrm{HO}\left[{ }^{57} \mathrm{Co}\right] \mathrm{Cbl}, \mathrm{TC}$ bovine transcobalamin

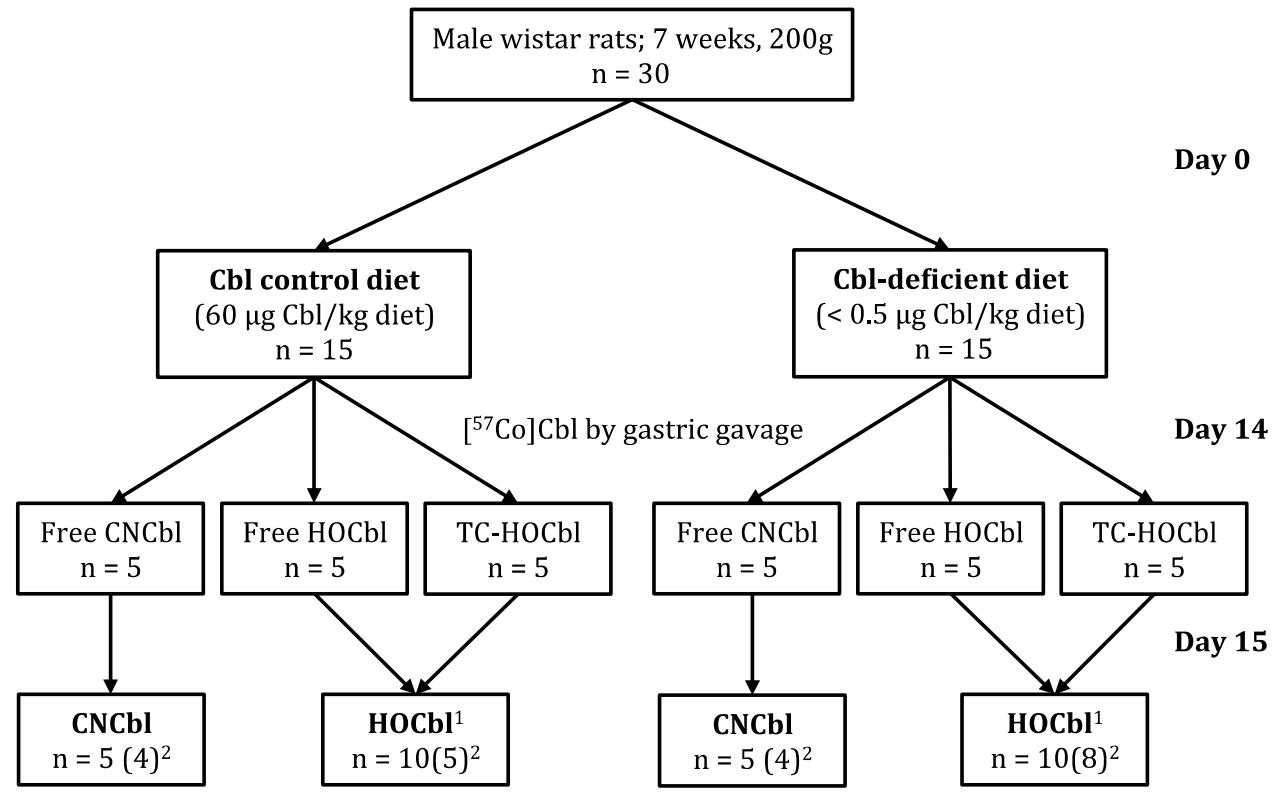

Cbl: Cobalamin; $\mathrm{CNCbl:} \mathrm{CN}\left[{ }^{57} \mathrm{Co}\right] \mathrm{Cbl}$; $\mathrm{HOCbl:} \mathrm{HO}\left[{ }^{57} \mathrm{Co}\right] \mathrm{Cbl}$; TC: bovine transcobalamin

1) No difference was observed whether HOCbl was given free or bound milk-TC. Thus, data was pooled.

2) Number of animals from which blood samples were successfully drawn is indicated in brackets.

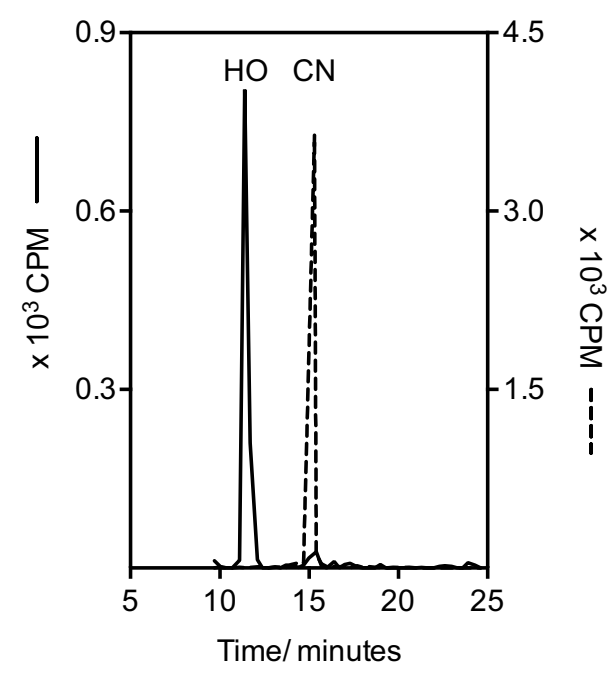

Fig. 2 HPLC profile of $\mathrm{HO}\left[{ }^{57} \mathrm{Co}\right] \mathrm{Cbl}$ after 5-month storage at $\mathrm{pH}$ $6.0,4^{\circ} \mathrm{C}$. Fractions were measured by gammacounter. The result is shown in full drawn line. For comparison, the elution profile of $\left.\mathrm{CN}^{57} \mathrm{Co}\right] \mathrm{Cbl}$ is shown in dashed line. $\mathrm{HO} \mathrm{HO}\left[{ }^{57} \mathrm{Co}\right] \mathrm{Cbl}, \mathrm{CN}$ $\mathrm{CN}\left[{ }^{57} \mathrm{Co}\right] \mathrm{Cbl}$

24-h faeces and $1 \mathrm{~mL}$ urine from each rat were counted. For the calculation of total plasma radioactivity, $\mathrm{cpm} / \mathrm{mL}$ plasma and estimates of total plasma volume were used [9]. For calculation of the total muscle $\mathrm{cpm}, \mathrm{cpm} / \mathrm{g}$ of muscle and an estimate of the total skeletal muscle mass based on body weight were used [10]. All results were expressed as a fraction of the total administered dose of $\left[{ }^{57} \mathrm{Co}\right] \mathrm{Cbl}$ per animal. Additional parameters were employed for analysis of the refined kinetics analysis; see supplementary material.

Six deficient and six normal rats were chosen randomly for the analysis of endogenous Cbl. The samples were thawed on the day of processing. From homogenous tissues, random $250 \mathrm{mg}$ was used (liver, muscle and spleen). From heterogeneous tissues, the apex of the heart, a quarter of a kidney and mixed cerebrum were used $(250 \mathrm{mg})$. We added $750 \mu \mathrm{L}$ of Na-acetate buffer $(0.4 \mathrm{~mol} / \mathrm{L}, \mathrm{pH}$ 4.4) to the individual tissue samples and homogenized at $6800 \mathrm{rpm}$ in three cycles of $20 \mathrm{~s}$ with $30 \mathrm{~s}$ pauses between cycles (Precellys 24, Bertin Technologies). After homogenisation, $20 \mu \mathrm{L} \mathrm{KCN}(30 \mathrm{mmol} / \mathrm{L})$ was added, and the mixtures were boiled $\left(100^{\circ} \mathrm{C}\right)$ for $10 \mathrm{~min}$. Supernatants for quantification of $\mathrm{Cbl}$ were collected after centrifugation (40 min; 20,000 $\times g$ ) and stored at $4{ }^{\circ} \mathrm{C}$ until analysed. The results were expressed as pmol Cbl per $\mathrm{g}$ of tissue or whole-organ $\mathrm{Cbl}$ (pmol; after multiplying by organ weight). Extraction of endogenous $\mathrm{Cbl}$ was $>90 \%$ as judged from independent experiments, where we added $\mathrm{HO}\left[{ }^{57} \mathrm{Co}\right] \mathrm{Cbl}$ to the homogenates prior to further treatment, and counted the amount of label remaining in the final supernatant.

To exclude confounding by a difference in biomarkers, we analysed markers of thyroid, liver and kidney function as well as markers of lipid metabolism, as outlined below.

We employed standard laboratory methods for analysing total Cbl (ADVIA Centaur CP immunoassay System, Siemens Healthcare Diagnostics, Denmark), triiodothyronine (T3), thyroxine (T4), alanine aminotransferase (ALAT), 
total cholesterol, triglyceride, carbamide (Cobas 6000, Roche Diagnostics) and methylmalonic acid (MMA) (6500 QTRAP mass spectrometer, AB Sciex, with a Shimadzu HPLC-system).

\section{Data analysis and statistical considerations}

Our initial analysis showed no difference between rats receiving $\mathrm{HO}\left[{ }^{57} \mathrm{Co}\right] \mathrm{Cbl}$ (free or bound to bovine TC) and no differences when comparing $\mathrm{CN}\left[{ }^{57} \mathrm{Co}\right] \mathrm{Cbl}$ with each $\mathrm{HO}\left[{ }^{57} \mathrm{Co}\right] \mathrm{Cbl}$ group alone, data not shown. Therefore, the two $\mathrm{HO}\left[{ }^{57} \mathrm{Co}\right] \mathrm{Cbl}$ groups were pooled (Figs. 1, 4). We used GraphPad Prism for Mac OS X, Version 6.0 e, for data analysis. $T$ test was used in the comparison of two groups. During analysis of ratios, the mean values of endogenous $\mathrm{Cbl}$ (or radioactivity from $\mathrm{CN}\left[{ }^{57} \mathrm{Co}\right] \mathrm{Cbl}$ or $\mathrm{HO}\left[{ }^{57} \mathrm{Co}\right] \mathrm{Cbl}$ ) in a tissue and plasma were expressed as (tissue $\mathrm{Cbl}$ )/ (plasma Cbl). The standard error of the obtained value was assessed from the relevant equation for propagation of uncertainties: $\operatorname{RSE}_{X / Y}^{2} \approx \operatorname{RSE}_{X}^{2}+\operatorname{RSE}_{Y}^{2}$ (RSE, relative standard error). All tests were considered statistically significant, when two-tailed $p$ values were $<0.05$.

\section{Theory of kinetic analysis}

The following nomenclature was used in the schemes (Fig. 3) and the below equations. Capitalized characters $A$, $B, C$, etc. denote the mass quantities of cobalamin present in different compartments (e.g. the intestinal walls, blood, tissues) with the volumes (masses) of $V_{A}, V_{B}, V_{C}$. Lowercase characters $a, b, c$, etc. correspond to the concentrations in the respective compartments. Exchange of $\mathrm{Cbl}$ is described by the "true" rate constants (e.g. $k_{a b}, k_{b a} \ldots$ ) for concentrations and the "apparent" rate constants (e.g. $k^{*}{ }_{A B}$, $\left.k^{*}{ }_{B A} \ldots\right)$ for masses. The sequence of subscript characters (e.g. in $k_{A B}^{*}$ or $k_{B A}^{*}$ ) shows the direction of transfer (e.g. $V_{A} \rightarrow V_{B}$ or $V_{B} \rightarrow V_{A}$ ).

Figure $3 \mathrm{a}$ depicts several examples of the considered kinetic schemes. Scheme 1 shows an equilibrium (e.g. $k_{x y}=k_{y x}$ and $x=y$ ), where the law of mass action stipulates the following expression:

$k_{x y} \cdot x=k_{y x} \cdot y$.

Scheme 2 depicts the identical exchange reaction, where the masses (e.g. $X=x \cdot V_{\mathrm{X}}$ ) are used instead of the concentrations. Here different volumes of compartments $\left(V_{X} \neq V_{Y}\right)$ cause an uneven distribution of the ligand quantities $(X \neq Y)$ despite the equality of concentrations at $k_{x y}=k_{y x}$ and $x=y$. Such situation requires the new equation of mass balance (Eq. 2).

$k_{X Y}^{*} \cdot X=k_{Y X}^{*} \cdot Y ; k_{X Y}^{*}=k_{x y} \frac{V_{Y}}{V_{X}+V_{Y}} ; k_{Y X}^{*}=k_{y x} \frac{V_{X}}{V_{X}+V_{Y}}$

Scheme 3 in Fig. 3a is an approximation that describes a unidirectional $\mathrm{Cbl}$ transport from the "excreting compartment" of the intestinal walls (pool $A$ ) to the blood pool $(B)$ and afterwards to different tissues (pool $C$ subdivided

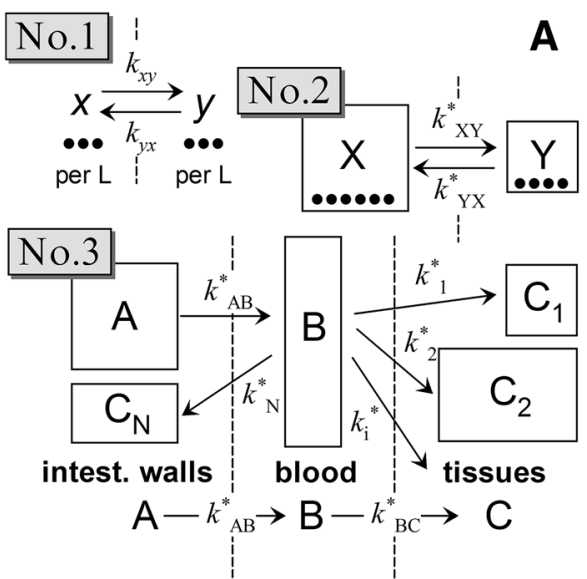

Fig. 3 The considered kinetic schemes and simulations. a Schemes 1 and 2 show the equilibrium exchange between two compartments and consider the concentration transfer (No. 1) and the total mass transfer (No. 2), respectively. The equal concentrations of $x$ and $y$ in Scheme 1 $\left(k_{x y}=k_{y x}\right)$ give different masses of $X$ and $Y$ in Scheme $2\left(k_{X Y}^{*} \neq k_{X Y}^{*}\right)$ if the two compartments have different volumes. Scheme 3 describes a unidirectional mass transfer of a metabolite between different compartments (metabolite pools $A, B$ and $C$ ). b Simulations of $\mathrm{Cbl}$ distribution between the pools $A, B$ and $C\left(A_{0}=50 \%\right)$. Solid lines correspond to the "plausible model" with $k^{*}{ }_{A B}=0.2 \mathrm{~h}^{-1}$ and

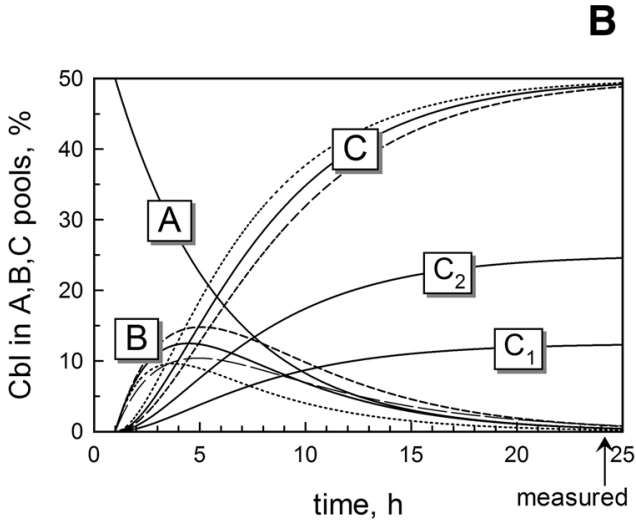

$k_{B C}^{*}=0.4 \mathrm{~h}^{-1}$. Curves $C_{1}$ and $C_{2}$ show two examples of Cbl accumulation in the two arbitrary organs 1 and 2 (from the tissue pool C) characterized by the mass transfer constants of $k^{*}{ }_{1}=0.1 \mathrm{~h}^{-1}$ and $k^{*}{ }_{2}=0.2 \mathrm{~h}^{-1}$, respectively. Short-dashed curves show changes in the kinetic records of $B$ and $C$ after decrease in the overall tissue accumulation constant $\left(k_{B C}^{*}=0.3 \mathrm{~h}^{-1}\right)$. Dotted curves show the analogous changes at its increase $\left(k_{B C}^{*}=0.6 \mathrm{~h}^{-1}\right)$. The thin longdashed curve for the metabolite $B$ depicts the time record for blood $\mathrm{Cbl}$ at a decreased transfer rate from the intestinal walls to plasma $\left(k^{*}{ }_{A B}=0.15 \mathrm{~h}^{-1}\right)$ 
into $C_{1}, C_{2}$, etc). It should be noted that this approximating model of irreversible transport results in $A$ and $B=0$ at $t \rightarrow \infty$, and it cannot be applied to an equilibrium. The scheme uses the apparent rate constants dependent on the compartment volumes $\left(k_{j}^{*}=k_{j} \cdot V_{j} / \mathrm{S} V_{j}\right)$. The kinetic equations of Scheme 3 can be presented as follows:

$A=A_{0} \cdot e^{-k_{A B^{-t}}^{*}}$

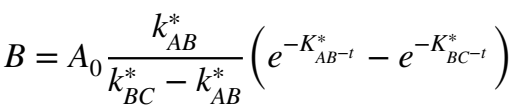

$C_{i}=A_{0} \frac{k_{i}^{*} k_{A B}^{*}}{k_{B C}^{*}-k_{A B}^{*}}\left[\frac{1}{k_{A B}^{*}}\left(1-e^{-k_{A B-t}^{*}}\right)-\frac{1}{k_{B C}^{*}}\left(1-e^{-k_{B C}^{*} t}\right)\right]$,

where $A_{0}$ is the amount of $\mathrm{Cbl}$ in the first compartment (pool A) at the start of transfer; $k^{*}{ }_{A B}$ and $k_{B C}^{*}$ are the apparent constants of transitions $A \rightarrow B$ and $B \rightarrow C$, respectively (where $C=\mathrm{SC}_{i}, k_{B C}^{*}=\mathrm{S} k_{i}^{*}$ ); $k^{*}{ }_{i}$ is the apparent rate constant of transfer from the pool $B$ to a particular compartment $C_{i} ; t$ is the apparent time of transportation equal to the real time after oral administration of $\mathrm{Cbl}$ minus $1 \mathrm{~h}$ $\left(t=t_{\text {real }}-1 \mathrm{~h}\right)$ to start the reactions from $\mathrm{Cbl}$ accumulated in the intestinal walls.

The possible curves of $\mathrm{Cbl}$ transfer from the intestinal walls $A$ to blood and tissues $(A \rightarrow B \rightarrow C)$ are presented in Fig. 3b. The shown records illustrate the expected shapes and the amplitudes of $\mathrm{Cbl}$ simulated for several sets of $k^{*}{ }_{A B}$ and $k_{B C}^{*}$. The Supplementary materials present more details concerning the theory and the assessment of constants.

\section{Results}

We studied rats fed for 2 weeks on a control diet $(60 \mu \mathrm{g}$ $\mathrm{Cbl} / \mathrm{kg})$ or a diet with a reduced Cbl content $(<0.5 \mu \mathrm{g} \mathrm{Cbl} /$ $\mathrm{kg}$ ).

Table 1 Basic characteristics for normal and Cbl-deficient rats
The basic characteristics of the normal and the deficient groups are displayed in Table 1. After 2 weeks on the Cbl-deficient diet, the rats showed biochemical signs of impaired $\mathrm{Cbl}$ status. Plasma Cbl values were sevenfold lower and MMA was approximately $30 \%$ higher in the deficient group compared with the normal group. The mean body weight of deficient rats was significantly lower $(286 \mathrm{~g}$; range 266-298) than that of normal rats (297 g; range 274-318), $p=0.02$. We found no significant differences in the organ weights (not shown) or in the analysed biomarkers of liver, endocrine or kidney functions (Table 1).

Table 2 displays tissue $\mathrm{Cbl}$ content of endogenous $\mathrm{Cbl}$ in both normal and deficient rats. The most dramatic differences were found in the kidneys, where $\mathrm{Cbl}$ was $93 \%$ lower in deficient compared with normal rats. The differences observed in other tissues were less pronounced.

We studied the 24-h absorption and tissue distribution of orally administered $\mathrm{CN}\left[{ }^{57} \mathrm{Co}\right] \mathrm{Cbl}$ (free) and $\mathrm{HO}\left[{ }^{57} \mathrm{Co}\right]$ $\mathrm{Cbl}$ (free or TC-bound). No differences were observed for free $\mathrm{HO}\left[{ }^{57} \mathrm{Co}\right] \mathrm{Cbl}$ compared with TC-bound $\mathrm{HO}\left[{ }^{57} \mathrm{Co}\right]$ Cbl regardless of the Cbl status of the rats (Figs. 4, 5). The results are in agreement with our previous studies for $\mathrm{CN}\left[{ }^{57} \mathrm{Co}\right] \mathrm{Cbl}[4]$, and we therefore conclude that $\mathrm{Cbl}$ (free or bound to TC) is absorbed and distributed alike. Therefore, in our present study, we combined data for uptake of free and TC-bound $\left.\mathrm{HO}^{57} \mathrm{Co}\right] \mathrm{Cbl}$. Figures 4 and 5 show the fractions of orally administered $\left[{ }^{57} \mathrm{Co}\right] \mathrm{Cbl}$ accumulated in each organ after $24 \mathrm{~h}$. The data for muscle and plasma (\% of the administered cpm per $\mathrm{g}$ and $\mathrm{mL}$, respectively) should be multiplied by $102 \pm 1.3 \mathrm{~g}$ and $10.2 \pm 0.3$ $\mathrm{mL}($ mean $\pm \mathrm{SD})$ to give the whole-organ counts. Total absorptions of $\mathrm{HO}\left[{ }^{57} \mathrm{Co}\right] \mathrm{Cbl}$ and $\mathrm{CN}\left[{ }^{57} \mathrm{Co}\right] \mathrm{Cbl}$ (equal to the administered dose minus the $\mathrm{cpm}$ recovered in intestines and faeces) accounted for approx. 55\% of the total administered dose with no significant difference between the groups (Fig. 5).

Distributional differences between the tissues, dependent on both $\mathrm{Cbl}$ status and administered $\left[{ }^{57} \mathrm{Co}\right] \mathrm{Cbl}$ form, were

\begin{tabular}{lccc}
\hline & Deficient $^{\mathrm{a}} n=12$ & Normal $^{\mathrm{a}} n=9$ & $p$ \\
\hline $\mathrm{Cbl}(\mathrm{pmol} / \mathrm{L})$ & $190(140-300)$ & $1330(1250-1480)$ & $<0.0001$ \\
$\mathrm{MMA}(\mu \mathrm{mol} / \mathrm{L})$ & $0.88(0.67-1.15)$ & $0.67(0.54-0.82)$ & 0.0003 \\
T3 $(\mathrm{nmol} / \mathrm{L})$ & $1.7(1.5-2.0)$ & $1.9(1.7-2.2)$ & 0.06 \\
T4 $(\mathrm{nmol} / \mathrm{L})$ & $72(64-84)$ & $74(62-96)$ & 0.78 \\
ALAT $(\mathrm{U} / \mathrm{L})$ & $20(9.0-29)$ & $23(9.0-35)$ & 0.15 \\
Carbamid $(\mathrm{mmol} / \mathrm{L})$ & $6.7(4.6-8.2)$ & $7.0(5.8-7.9)$ & 0.44 \\
Triglyceride $(\mathrm{mmol} / \mathrm{L})$ & $1.5(1.0-2.2)$ & $1.7(1.0-2.9)$ & 0.48 \\
Total cholesterol $(\mathrm{mmol} / \mathrm{L})$ & $2.5(2.1-3.4)$ & $2.3(1.7-2.9)$ & 0.42 \\
\hline
\end{tabular}

Rats were kept on a control diet $(60 \mu \mathrm{g} \mathrm{Cbl} / \mathrm{kg})$ or Cbl-deficient diet $(<0.5 \mu \mathrm{g} \mathrm{Cbl} / \mathrm{kg})$ for 2 weeks prior to sacrifice. Results are expressed as mean and (range). $p=$ exact $p$-values for comparison of the adjacent columns by two-sided $t$ tests

${ }^{a}$ Blood sampling failed in 3 deficient and 6 normal rats 
Table 2 Tissue contents of endogenous $\mathrm{Cbl}$ in normal and Cbl-deficient rats

\begin{tabular}{|c|c|c|c|c|}
\hline & \multicolumn{2}{|c|}{ Deficient $n=6$} & \multicolumn{2}{|l|}{ Normal $n=6$} \\
\hline & $\mathrm{pmol} \mathrm{Cbl/g}$ & Whole-organ $\mathrm{Cbl}$ (pmol) & $\mathrm{pmol} \mathrm{Cbl/g}$ & Whole-organ (pmol) \\
\hline Liver & $20(18-27)$ & $270(210-330)$ & $29(28-30)$ & $370(325-400)$ \\
\hline Kidneys & 85 (73-97) & $190(165-225)$ & $1160(1000-1270)$ & $2400(2110-2900)$ \\
\hline Spleen & $10(9-12)$ & $8(6-10)$ & $25(24-29)$ & $20(15-25)$ \\
\hline Heart & $28(27-28)$ & $29(24-40)$ & $49(47-51)$ & $51(47-54)$ \\
\hline Brain & $13(12-15)$ & $24(21-28)$ & $23(23-24)$ & $45(43-47)$ \\
\hline Muscle & $6(5-8)$ & $635(465-775)$ & $10(8-11)$ & $1010(885-1140)$ \\
\hline
\end{tabular}

Rats were kept for 2 weeks on a Cbl-deficient diet or control diet prior to sacrifice. Results are expressed as mean and (range) observed. Notably, deficient rats accumulated threefold less $\left[{ }^{57} \mathrm{Co}\right] \mathrm{Cbl}$ in the kidneys, but approximately twofold more in all other organs compared with normal rats. Significantly more $\mathrm{HO}\left[{ }^{57} \mathrm{Co}\right] \mathrm{Cbl}$ than $\mathrm{CN}\left[{ }^{57} \mathrm{Co}\right] \mathrm{Cbl}$ accumulated in the liver, while comparable amounts were found in the spleen and heart. Curiously, more $\mathrm{CN}\left[{ }^{57} \mathrm{Co}\right] \mathrm{Cbl}$ than $\left.\mathrm{HO}^{57} \mathrm{Co}\right]$ $\mathrm{Cbl}$ entered muscles and brain and remained in plasma.

We also explored the kinetics of $\left[{ }^{57} \mathrm{Co}\right] \mathrm{Cbl}$ uptake; the theoretical background and detailed discussion of which may be found in the supplementary material. This points out that the tissue/plasma ratio of $\left[{ }^{57} \mathrm{Co}\right] \mathrm{Cbl}$ concentrations is a simple, but illustrative tool to evaluate the basic features of transport kinetics. The ratio for each tissue either reflects its exchange rate constants at the equilibrium $\left(k_{\text {in }} / k_{\text {out }}\right.$, plasma $\leftrightarrow$ particular tissue $)$ or is proportional to a combination of several forward rate constants (intestine $\rightarrow$ plasma, plasma $\rightarrow$ all tissues, plasma $\rightarrow$ particular tissue) at a transient state. The analysis of ratios for endogenous Cbl (Fig. 6, open bars) shows quite high values and indicates a considerable shift towards $\mathrm{Cbl}$ accumulation in all organs of both normal (Fig. 6a) and Cbl-deficient (Fig. 6b) rats. Alignment of normal and deficient rats shows that vitamin deficiency decreases the kidney/plasma $\mathrm{Cbl}$ ratio significantly. All other tissues exhibited the opposite tendency, implying that the fractional uptake of circulating $\mathrm{Cbl}$ was higher in these tissues. In other words, the deficient rats exhibit a lower in/out transfer balance for the assumed "Cbl depository" kidney, but a higher in/out balance for any "Cbl-utilising" organ when compared with normal rats.

The relatively low values of transient tissue/plasma ratios for $\left[{ }^{57} \mathrm{Co}\right] \mathrm{Cbl} 24 \mathrm{~h}$ after administration (Fig. 6, closed bars, $\mathrm{HO} / \mathrm{CN}\left[{ }^{57} \mathrm{Co}\right] \mathrm{Cbl}$ ) indicate that the quasi-equilibrium state was not reached within in $24 \mathrm{~h}$. In normal rats, the spleen ratios are relatively close to the equilibrium values, while particularly the brain and muscle ratios have not reached the equilibrium values. Most tissues exhibit comparable figures for $\mathrm{HO}\left[{ }^{57} \mathrm{Co}\right] \mathrm{Cbl}$ and $\mathrm{CN}\left[{ }^{57} \mathrm{Co}\right] \mathrm{Cbl}$ (with a small, yet frequent preference for $\left.\mathrm{HO}\left[{ }^{57} \mathrm{Co}\right] \mathrm{Cbl}\right)$. However, in the liver, $\mathrm{HO}\left[{ }^{57} \mathrm{Co}\right] \mathrm{Cbl}$ uptake is more efficient than $\mathrm{CN}\left[{ }^{57} \mathrm{Co}\right] \mathrm{Cbl}$ uptake.

\section{Discussion}

We present data on endogenous $\mathrm{Cbl}$ and newly absorbed $\left[{ }^{57} \mathrm{Co}\right] \mathrm{Cbl}$ in both normal and Cbl-deficient rats. We employed two types of analyses to evaluate the dynamics of the $\mathrm{Cbl}$ distribution. First, we assessed $\left[{ }^{57} \mathrm{Co}\right] \mathrm{Cbl}$ accumulation in tissues. Second, we estimated the exchange balance between plasma and tissues (expressed via the ratio of mean Cbl concentrations: tissue/plasma). The analyses have some limitations because endogenous $\mathrm{Cbl}$ was measured in only six deficient and six normal rats. Plasma values were lacking in 9 animals; thus, the analysis of the transient state was undertaken for 21 of the 30 rats. Yet, we do not consider these limitations to detract from the value of our results since variations observed within each group of rats were small. We used the tissue/plasma ratio as a proxy for the exchange fluxes between the two compartments. This is obviously a simplification of more complex processes, but a reasonable picture can be outlined as long as we stick to a relative (and partially qualitative) assessment of data.

We induced $\mathrm{Cbl}$ depletion in rats by keeping them on a Cbl-deficient diet for 2 weeks. Plasma Cbl, MMA measurements and the endogenous $\mathrm{Cbl}$ content in kidneys (the Cbl storage organ in rats $[11,12])$ confirmed the deficient state. In accordance with previous data [12, 13], Cbl depletion was manifest in all tissues (most pronounced in kidneys). We found 93\% lower Cbl levels in deficient kidneys compared with normal kidneys. This value is comparable with the values reported for rats exposed to a deficient diet for up to several months [13-15]. In contrast, the difference in liver $\mathrm{Cbl}$ was remarkably smaller. Our rats showed only $30 \%$ lower liver $\mathrm{Cbl}$ levels in deficient compared with normal rats after 2 weeks. In literature, a more prolonged $\mathrm{Cbl}$ restriction led to a $60 \%$ decrease after 2 months or $54 \%$ after 3 months on the diet $[12,13]$. 
Liver

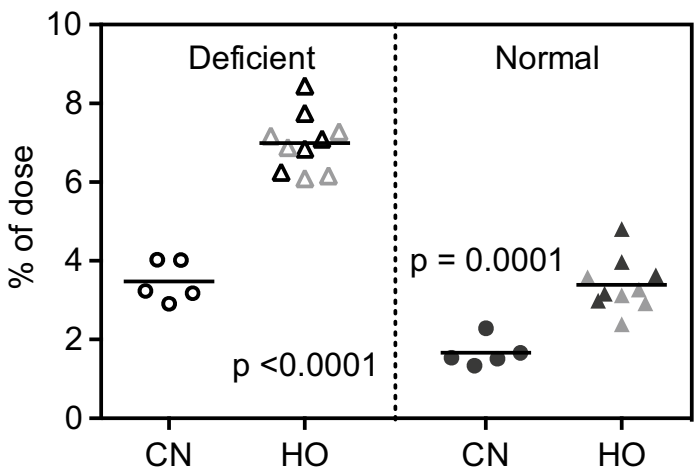

Spleen
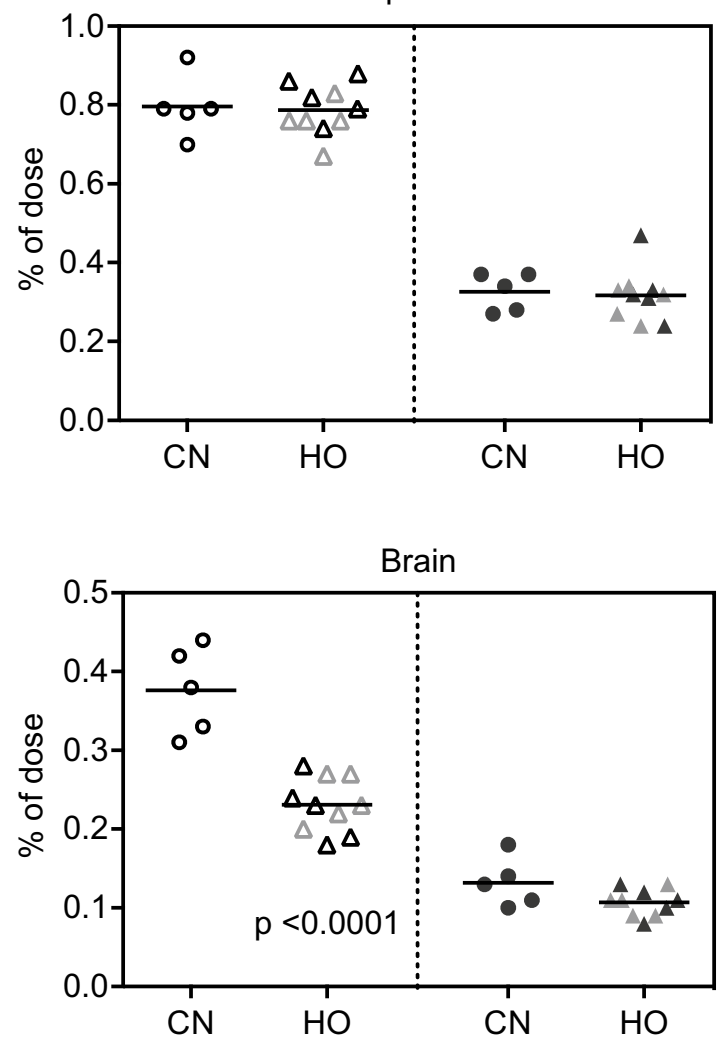

Fig. 4 Tissue $\left[{ }^{57} \mathrm{Co}\right] \mathrm{Cbl}$ accumulation in normal and deficient rats $24 \mathrm{~h}$ after oral administration of $\mathrm{CN}\left[{ }^{57} \mathrm{Co}\right] \mathrm{Cbl}(n=5$ in each group) or $\mathrm{HO}\left[{ }^{57} \mathrm{Co}\right] \mathrm{Cbl}$ ( $n=10$ in each group). Depicted are fractions of the administered $\left[{ }^{57} \mathrm{Co}\right] \mathrm{Cbl}$ present in the selected organs per whole organ or per $\mathrm{g}$ of muscle. Horizontal lines show the mean values.

We explored the 24-h absorption and tissue distribution of orally administered $\mathrm{HO}\left[{ }^{57} \mathrm{Co}\right] \mathrm{Cbl}$ compared with $\left.\mathrm{CN}^{57} \mathrm{Co}\right] \mathrm{Cbl}$ in both normal and deficient rats. In accordance with our previous data on normal rats [4], we observed comparable absorption levels of the two $\left[{ }^{57} \mathrm{Co}\right]$ $\mathrm{Cbl}$ forms in both normal and deficient rats. Interestingly, the tissue distributions of absorbed $\left[{ }^{57} \mathrm{Co}\right] \mathrm{Cbl}$ showed noticeable differences between deficient and normal rats
Kidneys

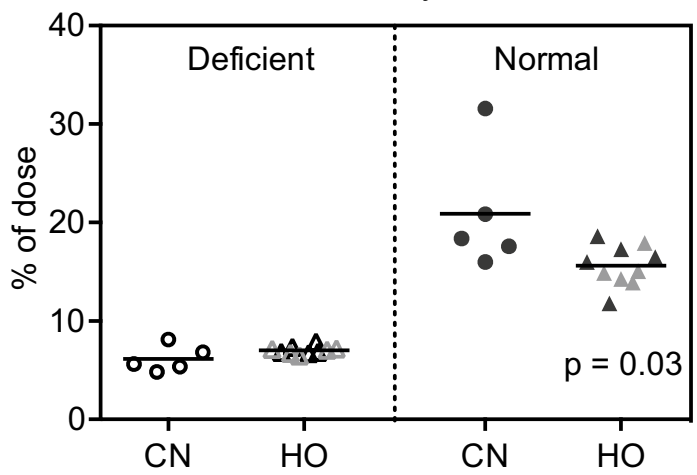

Heart
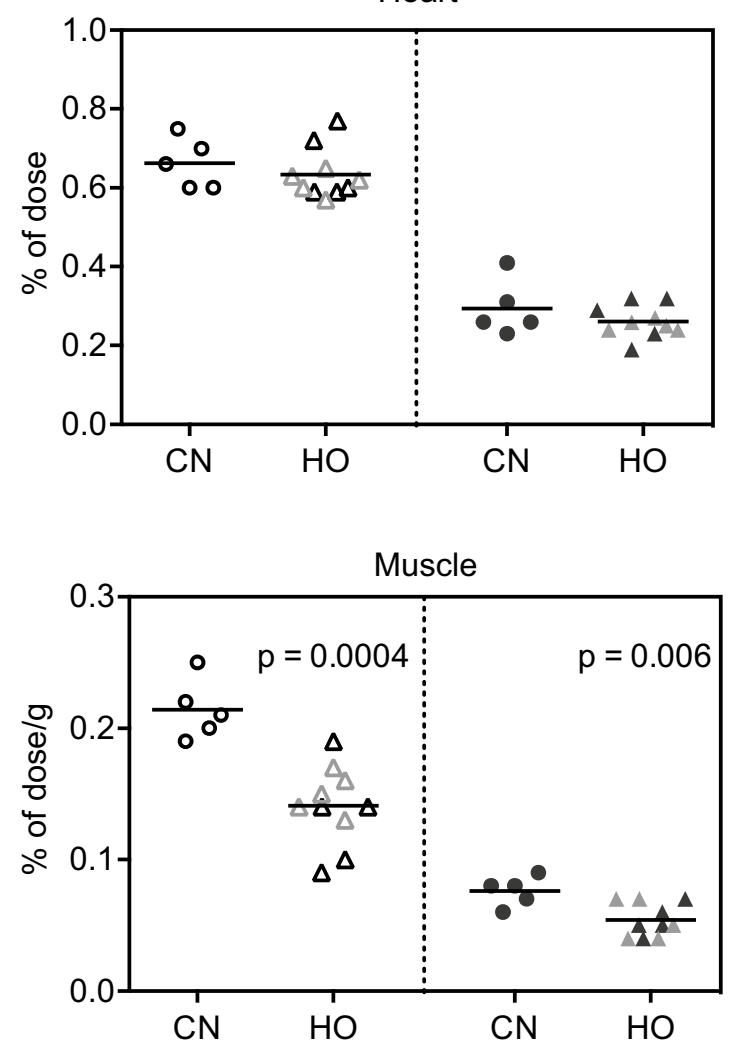

Scatter symbols indicate the values for the individual rats. Filled symbols normal; open symbols deficient; grey symbols $\mathrm{TC}-\mathrm{HO}\left[{ }^{57} \mathrm{Co}\right] \mathrm{Cbl}$. Probabilities of pairwise comparison of the adjacent scatter plots by the $t$ test are indicated. $\mathrm{Cbl}$ Cobalamin, $\mathrm{CNCbl} \mathrm{CN}\left[{ }^{57} \mathrm{Co}\right] \mathrm{Cbl}, \mathrm{HOCbl}$ $\mathrm{HO}\left[{ }^{57} \mathrm{Co}\right] \mathrm{Cbl}, T C$ bovine transcobalamin

as well as between $\left.\mathrm{HO}^{57} \mathrm{Co}\right] \mathrm{Cbl}$ and $\mathrm{CN}\left[{ }^{57} \mathrm{Co}\right] \mathrm{Cbl}$. The liver uptake of $\mathrm{HO}\left[{ }^{57} \mathrm{Co}\right] \mathrm{Cbl}$ was more than twice that of $\mathrm{CN}\left[{ }^{57} \mathrm{Co}\right] \mathrm{Cbl}$, while the brain accumulated more $\mathrm{CN}\left[{ }^{57} \mathrm{Co}\right]$ $\mathrm{Cbl}$ than $\mathrm{HO}\left[{ }^{57} \mathrm{Co}\right] \mathrm{Cbl}$, especially in deficient rats. These results confirm and expand previous findings [4, 16, 17] about higher accumulation of $\mathrm{HO}\left[{ }^{57} \mathrm{Co}\right] \mathrm{Cbl}$ in the liver and of $\mathrm{CN}\left[{ }^{57} \mathrm{Co}\right] \mathrm{Cbl}$ in the kidney. Now we show that tissue accumulation patterns apparently fall into three categories: 
Plasma
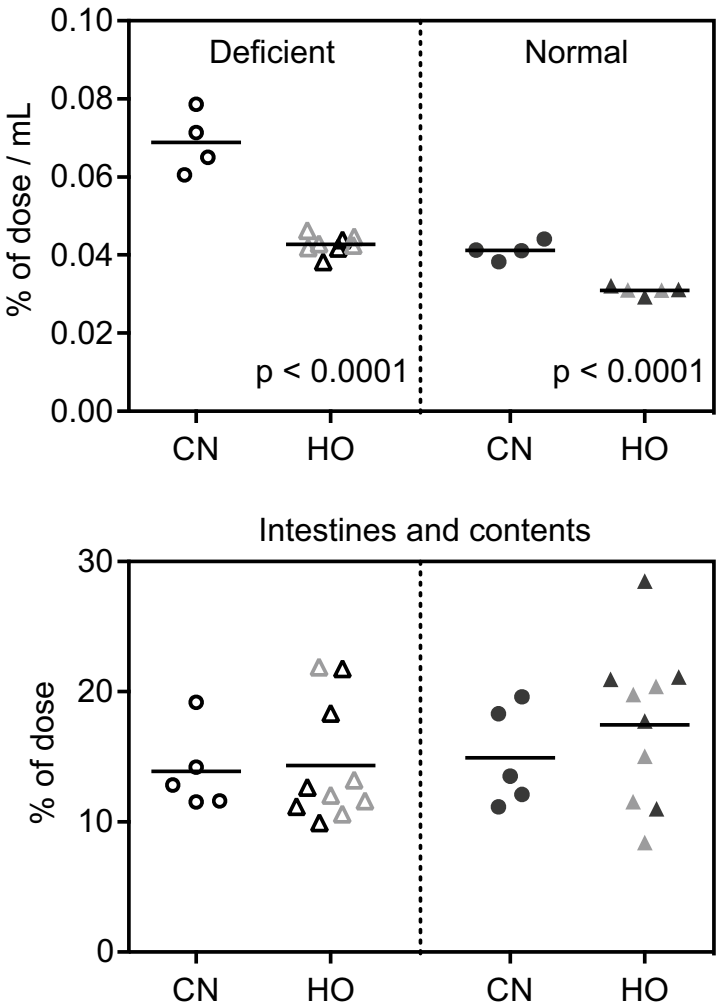

Fig. 5 Tissue $\left[{ }^{57} \mathrm{Co}\right] \mathrm{Cbl}$ accumulation in normal and deficient rats $24 \mathrm{~h}$ after oral administration of $\left.\mathrm{CN}^{57} \mathrm{Co}\right] \mathrm{Cbl}(n=5$ in each group) or $\mathrm{HO}\left[{ }^{57} \mathrm{Co}\right] \mathrm{Cbl}(n=10$ in each group). Depicted are fractions of administered $\left[{ }^{57} \mathrm{Co}\right] \mathrm{Cbl}$ present in plasma (per $\mathrm{mL}$ ), whole intestines (incl. contents), urine and total absorption. Total absorption $=$ (administered dose minus cpm in 'intestines and contents' and faeces)/admin-
Total absorption
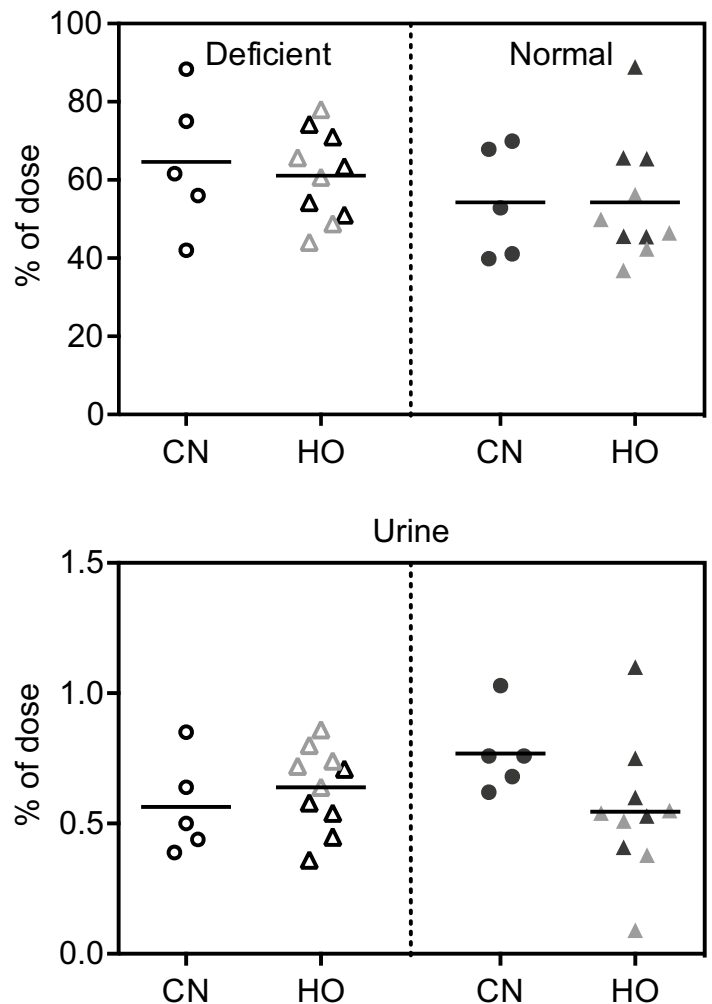

istered dose. Horizontal lines show the mean values. Scatter symbols indicate the values for the individual rats. Filled symbols normal, open symbols deficient, grey symbols $\mathrm{TC}-\mathrm{HO}\left[{ }^{57} \mathrm{Co}\right] \mathrm{Cbl}$. Probabilities of pairwise comparison of the adjacent scatter plots by $t$ test are indicated. $\mathrm{Cbl}$ Cobalamin, $\mathrm{CNCbl} \mathrm{CN}\left[{ }^{57} \mathrm{Co}\right] \mathrm{Cbl}$, HOCbl $\mathrm{HO}\left[{ }^{57} \mathrm{Co}\right] \mathrm{Cbl}$, $T C$ bovine transcobalamin

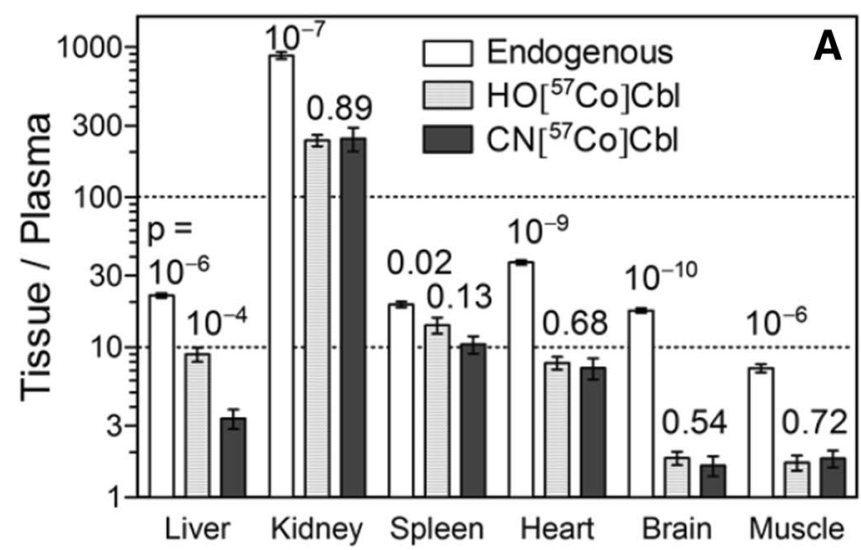

Fig. 6 Ratios (mean tissue Cbl/mean plasma $\mathrm{Cbl}$ ) of endogenous $\mathrm{Cbl}(\mathrm{pmol} / \mathrm{g}) /(\mathrm{pmol} / \mathrm{mL}$ ) (open bars, $n=6$ normal and, $n=6$ deficient) and labelled $\mathrm{Cbl}(\mathrm{cpm} / \mathrm{g}) /(\mathrm{cpm} / \mathrm{mL})$, accumulated $24 \mathrm{~h}$ after administration of oral $\mathrm{HO}\left[{ }^{57} \mathrm{Co}\right] \mathrm{Cbl}$ (spotted bars, $n=5$ normal and $n=8$ deficient) or $\left.\mathrm{CN}^{57} \mathrm{Co}\right] \mathrm{Cbl}$ (closed bars, $n=4$ normal and $n=4$ deficient) in rats kept on a $\mathrm{Cbl}$ control (a) or a deficient (b) diet for

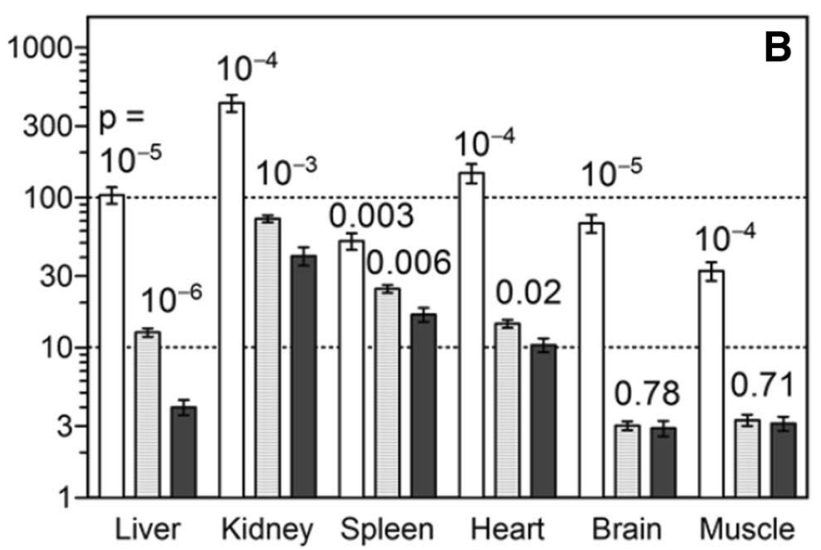

2 weeks. The mean ratio (bar) and \pm SEM (vertical whisker lines) are indicated. Dashed horizontal lines are depicted to simplify comparison of bars. Probabilities of pairwise comparison of the adjacent bars by $t$ test are indicated. $X$-axis indicates the organs examined. $\mathrm{Y}$-axis indicates tissue/plasma ratio, log-scale. $\mathrm{Cbl}$ Cobalamin, $\mathrm{CNCbl}$ $\mathrm{CN}\left[{ }^{57} \mathrm{Co}\right] \mathrm{Cbl}, \mathrm{HOCbl} \mathrm{HO}\left[{ }^{57} \mathrm{Co}\right] \mathrm{Cbl}, \mathrm{TC}$ bovine transcobalamin 
tissues with a preference for $\mathrm{HO}\left[{ }^{57} \mathrm{Co}\right] \mathrm{Cbl}$ (liver), tissues accumulating comparable amounts of $\mathrm{HO}\left[{ }^{57} \mathrm{Co}\right] \mathrm{Cbl}$ and $\mathrm{CN}\left[{ }^{57} \mathrm{Co}\right] \mathrm{Cbl}$ (the spleen and heart; and the kidney of deficient rats), and tissues with a preference for $\left.\mathrm{CN}^{57} \mathrm{Co}\right] \mathrm{Cbl}$ (brain and muscle; and the kidney of normal rats).

Most previous studies investigated distribution of parenterally administered $\mathrm{Cbl}$, which complicates the comparison of our results with earlier data. However, Adams et al. compared oral absorptions of labelled CNCbl, HOCbl and $\mathrm{MeCbl}$ in 63 patients [14]. Administration of $1 \mu \mathrm{g}$ resulted in mean whole-body retentions of $56 \%(\mathrm{HOCbl})$ and $49 \%$ $(\mathrm{CNCbl})$ after 16 days, which is comparable to our figures obtained $24 \mathrm{~h}$ after $\mathrm{Cbl}$ supplementation. Interestingly, these values confirm that $\mathrm{HOCbl}$ and $\mathrm{CNCbl}$ show a comparable uptake in humans, too.

It should be stressed that higher or lower tissue loads with either one or the other $\left[{ }^{57} \mathrm{Co}\right] \mathrm{Cbl}$ form are not a reflection of the individual tissue kinetics, but the result of a combination of parameters for all tissues (see the supplementary material for more details). Presenting this subject in a nutshell: if a ligand $X$ vs. $Y$ has low ability to enter e.g. the liver, the "remaining" quantity of $X$ in the blood will overload all other tissues. In other words, higher uptake levels of $\mathrm{CN}\left[{ }^{57} \mathrm{Co}\right] \mathrm{Cbl}$ vs. $\mathrm{HO}\left[{ }^{57} \mathrm{Co}\right] \mathrm{Cbl}$ in, e.g. the muscles and brain (Fig. 4e, f) do not necessarily equal faster $\mathrm{CN}\left[{ }^{57} \mathrm{Co}\right] \mathrm{Cbl}$ accumulation, but might reflect a slower transport of this ligand into other tissues (e.g. liver). Keeping this in mind, we undertook an analysis of $\mathrm{Cbl}$ ratios (tissue/plasma), which provides a more adequate description of the true kinetics of $\mathrm{Cbl}$ distribution.

First of all, we observed lower tissue/plasma ratios for newly administered $\left[{ }^{57} \mathrm{Co}\right] \mathrm{Cbls}(24 \mathrm{~h})$ than for endogenous $\mathrm{Cbl}$ in both normal and deficient rats (Fig. 6). We believe that this finding indicates that the equilibrium is not reached, and that $\left[{ }^{57} \mathrm{Co}\right] \mathrm{Cbl}$ uptake is still in progress. In the spleen of normal rats, tissue/plasma ratios for newly absorbed $\left[{ }^{57} \mathrm{Co}\right] \mathrm{Cbl}$ came closest to the near-equilibrium level, which suggests a rather fast $\mathrm{Cbl}$ turnover in this organ (high $k_{\text {in }}$ and a relatively high $k_{\text {out }}$ ). The largest difference in tissue/plasma levels between endogenous and newly absorbed $\left[{ }^{57} \mathrm{Co}\right] \mathrm{Cbls}$ was seen in muscle and brain, which probably implies a slower $\mathrm{Cbl}$ turnover in these organs.

The observations for plasma Cbl warrant further comments, because in both deficient and normal rats the 24-h plasma samples contain more $\mathrm{CN}\left[{ }^{57} \mathrm{Co}\right] \mathrm{Cbl}$ than $\mathrm{HO}\left[{ }^{57} \mathrm{Co}\right]$ Cbl. Several explanations, as well as combinations of explanations, are possible if we take the time of measurement into account (well after the peak of plasma $\left[{ }^{57} \mathrm{Co}\right] \mathrm{Cbl}$ at $4 \mathrm{~h}$ for rats [15]). For example, a slower $\mathrm{CN}\left[{ }^{57} \mathrm{Co}\right] \mathrm{Cbl}$ clearance (plasma $\rightarrow$ tissues) is a self-suggesting reason, see Fig. 3b (short-dashed modelling curve for $B$-metabolite). Slower $\mathrm{CN}\left[{ }^{57} \mathrm{Co}\right] \mathrm{Cbl}$ transportation from intestine to plasma is another feasible explanation, because a "tailing" of plasma $\left[{ }^{57} \mathrm{Co}\right] \mathrm{Cbl}$ over time is expected in such case (thin, long-dashed curve in Fig. 3b). Finally, a faster backward $\mathrm{CN}\left[{ }^{57} \mathrm{Co}\right] \mathrm{Cbl}$ excretion from tissues to plasma (i.e. a better retention of $\left.\mathrm{HO}^{57} \mathrm{Co}\right] \mathrm{Cbl}$ compared with $\mathrm{CN}\left[{ }^{57} \mathrm{Co}\right]$ $\mathrm{Cbl}$ in the tissues) may be in play. In the latter situation, the bars for "transient" $\mathrm{CN}\left[{ }^{57} \mathrm{Co}\right] \mathrm{Cbl}$ in Fig. 6 may correspond to a "worsened" near-equilibrium balance (more $\left[{ }^{57} \mathrm{Co}\right]$ $\mathrm{Cbl}$ outside) rather than to the decelerated forward transportation. The suggestion of a better $\left.\mathrm{HO}^{57} \mathrm{Co}\right] \mathrm{Cbl}$ retention could be true if $\mathrm{HO}\left[{ }^{57} \mathrm{Co}\right] \mathrm{Cbl}$ is more easily converted into the active coenzyme $\mathrm{Cbl}$ forms. Regarding this subject, Uchino et al. described a threefold higher conversion of $\mathrm{HOCbl}$ than $\mathrm{CNCbl}$ to Ado-Cbl in rat liver $24 \mathrm{~h}$ after intravenous injection [16]. Other authors found that serum-Cbl increased faster [18, 19] and remained at a higher level for a longer period of time after intramuscular $\mathrm{HOCbl}$ injection than after $\mathrm{CNCbl}$ injection [18]. Additionally, whole-body retention was higher [20] and urinary excretion lower [19, 21] after $\mathrm{HOCbl}$ than after $\mathrm{CNCbl}$ injection.

From a biological point of view, it is easy to accept that affinity for the naturally occurring $\mathrm{Cbl}$ may be higher than for the synthetic form with a resulting higher accumulation of $\mathrm{HO}\left[{ }^{57} \mathrm{Co}\right] \mathrm{Cbl}$ in tissues compared with $\mathrm{CN}\left[{ }^{57} \mathrm{Co}\right]$ Cbl. In addition, $\mathrm{HO}\left[{ }^{57} \mathrm{Co}\right] \mathrm{Cbl}$ is much more susceptible to reduction (a necessary step in conversion to the cofactors) than $\mathrm{CN}\left[{ }^{57} \mathrm{Co}\right] \mathrm{Cbl}$. It is therefore remarkable that brain and muscle tissue accumulate more $\mathrm{CN}\left[{ }^{57} \mathrm{Co}\right] \mathrm{Cbl}$ than $\mathrm{HO}\left[{ }^{57} \mathrm{Co}\right] \mathrm{Cbl}$ in both normal and deficient rats (Fig. 4e, f). Yet, $\mathrm{CN}\left[{ }^{57} \mathrm{Co}\right] \mathrm{Cbl}$ "overloading" of the brain and muscle may be the direct consequence of "underloading" in other tissues.

Analysis of ratios in Fig. 6 (especially for deficient rats, Fig. 6b) reveals higher ratios for $\mathrm{HO}\left[{ }^{57} \mathrm{Co}\right] \mathrm{Cbl}$ than for $\mathrm{CN}\left[{ }^{57} \mathrm{Co}\right] \mathrm{Cbl}$ in a number of tissues (though with different levels of significance). A higher ratio in the non-equilibrium state (Fig. 3a, Scheme 3) requires a faster transportation at one or more forward steps (intestine $\rightarrow$ plasma; plasma $\rightarrow$ all tissues; plasma $\rightarrow$ particular tissue). A higher ratio at the equilibrium (Fig. 3a, Scheme 1) means a shift towards tissue accumulation (plasma $\leftrightarrow$ particular tissue). Whatever the reason might be, $\mathrm{HO}\left[{ }^{57} \mathrm{Co}\right] \mathrm{Cbl}$ appears to be a better choice for faster load into most tissues and/or better internalization percentage. Similar ratio bars for $\left.\mathrm{CN}^{57} \mathrm{Co}\right]$ $\mathrm{Cbl}$ vs. $\left.\mathrm{HO}^{57} \mathrm{Co}\right] \mathrm{Cbl}$ for brain and muscle (Fig. 6) apparently indicate a lacking preference for the vitamin form.

$\left[{ }^{57} \mathrm{Co}\right] \mathrm{Cbl}$ flux balance (expressed by its tissue/plasma ratio) shows a much lower fractional accumulation in deficient than in normal kidneys, while this parameter increases in all other organs. Usually, rat kidneys accumulate large quantities of $\mathrm{Cbl}$ disregarding the small size of this organ. The difference between kidney and other tissues may relate to kidney ultra-filtration and reabsorption of the transcobalamin-Cbl complex by the megalin receptor present in 
proximal tubules [22]. The kidney has a high capacity to accumulate ultra-filtrated Cbl, which is likely to be directly related to plasma $\mathrm{Cbl}$ concentration. Additionally, the $\mathrm{Cbl}$ dynamics of the kidney supports its role as a $\mathrm{Cbl}$ storage organ. A higher plasma $\left[{ }^{57} \mathrm{Co}\right] \mathrm{Cbl}$ in deficient rats will cause a higher kidney $\left[{ }^{57} \mathrm{Co}\right] \mathrm{Cbl}$ ultrafiltration. This also implies a higher reabsorption of $\left[{ }^{57} \mathrm{Co}\right] \mathrm{Cbl}$ in the proximal tubules of deficient rats since the same level of urine $\left[{ }^{57} \mathrm{Co}\right]$ $\mathrm{Cbl}$ was found in the two groups $(p=0.94)$. However, less $\left[{ }^{57} \mathrm{Co}\right] \mathrm{Cbl}$ is withheld in deficient kidneys at $24 \mathrm{~h}$, which indicates an increased export from the kidneys to plasma, maintaining a sufficient $\mathrm{Cbl}$ supply of other tissues. Kidney $\left[{ }^{57} \mathrm{Co}\right] \mathrm{Cbl}$ excretion to urine did not deviate significantly between the two $\left[{ }^{57} \mathrm{Co}\right] \mathrm{Cbl}$ forms. In summary, kidney $\left[{ }^{57} \mathrm{Co}\right] \mathrm{Cbl}$ accumulation, distribution and excretion into urine change according to the current $\mathrm{Cbl}$ status. A regulated $\mathrm{Cbl}$ export in kidneys has been suggested in the literature [12], but has, to the best of our knowledge, never previously been reported.

In conclusion, our study demonstrates differences in $\mathrm{Cbl}$ distribution dependent on both the current $\mathrm{Cbl}$ status and the administered $\mathrm{Cbl}$ form. It is well recognized that both forms of $\mathrm{Cbl}$ are eventually converted to the two coenzyme forms of $\mathrm{Cbl}$ [16], but an earlier clinical study showed that in humans the major part of $\mathrm{CNCbl}$ is absorbed without conversion to other forms [23]. Our results warrant a long-term investigation to clarify the differences in tissue distribution of administered $\mathrm{HO}\left[{ }^{57} \mathrm{Co}\right] \mathrm{Cbl}$ compared with $\mathrm{CN}\left[{ }^{57} \mathrm{Co}\right] \mathrm{Cbl}$ in order to establish their efficacy for supplementation and treatment.

Acknowledgements This study is part of the TRIM Project, which is financed by Innovation Fund Denmark, Grant No. 12-132437. We warmly appreciate the competent technical assistance provided by Jette Fisker Pedersen and Inger Marie Jensen.

\section{Compliance with ethical standards}

Conflict of interest The authors declare that they have no conflict of interest.

Open Access This article is distributed under the terms of the Creative Commons Attribution 4.0 International License (http:// creativecommons.org/licenses/by/4.0/), which permits unrestricted use, distribution, and reproduction in any medium, provided you give appropriate credit to the original author(s) and the source, provide a link to the Creative Commons license, and indicate if changes were made.

\section{References}

1. Nielsen MJ, Rasmussen MR, Andersen CBF et al (2012) Vitamin B12 transport from food to the body's cells: a sophisticated, multistep pathway. Nat Rev Gastroenterol Hepatol 9:345-354. doi:10.1038/nrgastro.2012.76
2. Farquharson J, Adams JF (1976) The forms of vitamin B12 in foods. Br J Nutr 36:127-136. doi:10.1079/BJN19760063

3. Obeid R, Fedosov SN, Nexo E (2015) Cobalamin coenzyme forms are not likely to be superior to cyano- and hydroxyl-cobalamin in prevention or treatment of cobalamin deficiency. Mol Nutr Food Res 59 (7):1364-1372. doi:10.1002/mnfr.201500019

4. Kornerup LS, Juul CB, Fedosov SN et al (2016) Absorption and retention of free and milk protein-bound cyano- and hydroxocobalamins. An experimental study in rats. Biochimie 126:57-62. doi:10.1016/j.biochi.2015.11.024

5. Greibe E, Nexo E (2016) Forms and amounts of Vitamin B12 in infant formula: a pilot study. PLoS ONE 11:e0165458. doi:10.1371/journal.pone. 0165458

6. Marcus AD, Stanley JL (1964) Stability of the cobalamin moiety in buffered aqueous solutions of hydroxocobalamin. J Pharm Sci 53:91-94. doi:10.1002/jps.2600530118

7. Fedosov SN, Berglund L, Nexø E, Petersen TE (1999) Sequence, S-S bridges, and spectra of bovine transcobalamin expressed in Pichia pastoris. J Biol Chem 274:26015-26020.

8. Fedosov SN, Fedosova NU, Nexø E, Petersen TE (2000) Conformational changes of transcobalamin induced by aquocobalamin binding. J Biol Chem 275:11791-11798

9. Lee HB, Blaufox MD (1985) Blood volume in the rat. J Nucl Med 25:72-76

10. Widmer HR, Hoppeler H, Nevo E et al (1997) Working underground: respiratory adaptations in the blind molar rat. Proc Natl Acad Sci 94:2062-2067.

11. Harte RA, Chow BF, Barrows L (1953) Storage and elimination of vitamin B12 in the rat. J Nutr 49:669-678

12. Scott JS, Treston AM, Bowman EP et al (1984) The regulatory roles of liver and kidney in cobalamin (vitamin B12) metabolism in the rat: the uptake and intracellular binding of cobalamin and the activity of the cobalamin-dependent enzymes in response to varying cobalamin supply. Clin Sci (Lond) 67:299-306

13. Birn H, Nexo E, Christensen EI, Nielsen R (2003) Diversity in rat tissue accumulation of vitamin B12 supports a distinct role for the kidney in vitamin B12 homeostasis. Nephrol Dial Transplant 18:1095-1100. doi:10.1093/ndt/gfg089

14. Adams JF, Ross SK, Mervyn L et al (1971) Absorption of cyanocobalamin, coenzyme B 12, methylcobalamin, and hydroxocobalamin at different dose levels. Scand J Gastroenterol 6:249252. doi: $10.3109 / 00365527109180702$

15. Booth CC, Chanarin I, Anderson BB, Mollin DL (1957) The site of absorption and tissue distribution of orally administered 56Co-labelled vitamin B12 in the rat. Br J Haematol 3:253-261

16. Uchino H, Yagiri Y, Yoshino T et al (1965) Conversion of cyanoand hydroxo-cobalamin in vivo into co-enzyme form of vitamin B12 in the rat. Nature 205:176-177. doi:10.1038/205176b0

17. Heinrich HC, Gabbe EE (1964) Metabolism of the vitamin B12-coenzyme in rats and man. Ann New York Acad Sci 112:871-903. doi:10.1111/j.1749-6632.1964.tb45064.x

18. Chalmers JN, Shinton NK (1965) Comparison of hydroxocobalamin and cyanocobalamin in the treatment of pernicious anaemia. The Lancet 2:1305-1308. doi:10.1016/S0140-6736(65)92336-6

19. Glass GB, Skeggs HR, Lee DH et al (1961) Hydroxocobalamin. I. Blood levels and urinary excretion of vitamin B12 in man after a single parenteral dose of aqueous hydroxocobalamin, aqueous cyano-cobalamin and cyanocobalamin zinc-tannate complex. Blood 18:511-521

20. Boddy K, King P, Mervyn L et al (1968) Retention of cyanocobalamin, hydroxocobalamin, and coenzyme B12 after parenteral administration. Lancet 2:710-712. doi:10.1016/ S0140-6736(68)90752-6

21. Herbert V, Zalusky R, Skeggs HR (1963) Retention of injected hydroxocobalamin versus cyanocobalamin versus liver extractbound cobalamin. Am J Clin Nutr 12:145-149 
22. Moestrup SK, Birn H, Fischer PB et al (1996) Megalin-mediated endocytosis of transcobalamin-vitamin-B12 complexes suggests a role of the receptor in vitamin-B12 homeostasis. Proc Natl Acad Sci USA 93:8612-8617. doi:10.1073/pnas.93.16.8612
23. Hardlei TF, Mørkbak AL, Bor MV et al (2010) Assessment of vitamin $\mathrm{B}(12)$ absorption based on the accumulation of orally administered cyanocobalamin on transcobalamin. Clin Chem 56:432-436. doi:10.1373/clinchem.2009.131524 